\title{
RELASI KUASA DAN SIMBOL-SIMBOL EKONOMI-POLITIK GEREJA DALAM KONTESTASI POLITIK LOKAL PROVINSI NTT
}

\author{
Mikhael Rajamuda Bataona ${ }^{1}$ dan Atwar Bajari² \\ ${ }^{1}$ Universitas Katolik Widya Mandira Kupang \\ ${ }^{2}$ Universitas Padjadjaran
}

\begin{abstract}
ABSTRAK
Studi ini menyingkap relasi kuasa antara aktor atau rezim politik dengan otoritas gereja dalam kontestasi politik lokal di Nusa Tenggara Timur (NTT). Bagaimana relasi kuasa tersebut menyembunyikan barter kepentingan ekonomi-politik. Menggunakan empat pisau analisis, yaitu: Dekonstruksi dari Jaques Derida; Modal, Habitus, Kekuasaan simbolik, dan Kekerasan Simbolik dari Pierre Bourdieu; Relasi Kuasa/ Pengetahuan dari Michel Foucault; dan Diskursus dari Jurgen Habermas, studi ini menemukan fakta adanya dominasi dan hegemoni terhadap umat dan adanya motif ekonomi-politik di balik relasi kuasa tersebut. Studi tentang barter kepentingan gereja dan rezim politik di NTT belum pernah dilakukan. Praktik politik ini bahkan telah menjadi sebuah budaya politik di NTT yang terus berulang dalam setiap Pemilu. Kesadaran umat di NTT juga telah dimanipulasi. Baik melalui dominasi langsung, yaitu melalui perintah dan aturan gereja. Maupuan hegemoni, yaitu melalui wacana ideologis yang didistribusikan untuk menormalisasi cara pandang umat. Tujuannya adalah untuk mendapat manfaat elektoral dalam setiap pemilu. Umat akhirnya terus mengalami kekerasan simbolik. Tujuan studi ini adalah untuk menginisiasi sebuah gerakan emansipasi lewat wacana-wacana kontra-hegemoni di ruang-ruang publik di NTT dan advokasi terhadap umat. Sasarannya adalah untuk mentransformasi kesadaran umat dan masyarakat NTT pada umumnya, untuk menjadi lebih demokratis dan manusiawi.
\end{abstract}

Kata-kata Kunci: Ideologi, dominasi-hegemoni, kekerasan simbolik, kontra-hegemoni, transformasi

\section{POWER RELATION AND SYMBOLS OF POLITICAL-ECONOMY OF THE CHURCH IN LOCAL POLITICAL CONTESTATION OF EAST NUSA TENGGARA PROVINCE}

\begin{abstract}
This study reveals the power relations between political actors or regimes and church authorities in local political contestation in East Nusa Tenggara (NTT). How the power relations hide the barter of economicpolitical interests. Using four analytical blades, 1) Deconstruction of Jaques Derida, 2) Capital, Habitus, Symbolic Powers, and Symbolic Violence of Pierre Bourdieu, 3) Relation of Power / Knowledge from Michel Foucault, and 4) Discourse from Jurgen Habermas, this study Found the fact of domination and hegemony against the ummah and the existence of the political-economic motive behind the power relation. The study of barter of church interest and political regime in NTT, has never been done. This political practice has even become a political culture in NTT that keeps repeating itself in every election. People's awareness in NTT has also been manipulated. Both through direct domination, through the orders and rules of the church. Maupuan hegemony, ie through ideological discourse which is distributed to normalize the worldview. The aim is to get electoral benefits in every election. The people end up continuously experiencing symbolic violence. The aim of this study was to initiate a movement of emancipation through counter-hegemonic discourse in public spaces in NTT and advocacy towards the ummah. The goal is to transform the consciousness of NTT people and society in general, to become more democratic and humane.
\end{abstract}

Keywords: Ideology, dominance-hegemony, symbolic violence, counter-hegemony, transformation

Korespondensi: Mikhael Rajamuda Bataona, M.I.Kom. Fakultas Ilmu Sosial dan Politik, Universitas Katolik Widya Mandira-Kupang. Jln. San Juan-Penfui, Kota Kupang, Provinsi Nusa Tenggara Timur (NTT). Email: erlandlamalera@gmail.com. 


\section{PENDAHULUAN}

Dalam studinya tentang demokrasi dan politik kontemporer di Indonesia pasca lengsernya Soeharto, peneliti Nordholt (2008: 17) telah menunjukan dengan jelas bahwa, meskipun telah terselenggaranya pemilihan langsung dalam rangka rekruitmen pemimpin politik, demokrasi di Indonesia belum berbasis aturan hukum yang kuat dan tidak berwatak transparan juga akuntabel. Meminjam kata-kata profesor Sejarah Indonesia itu sendiri: "One of the greatest achievements of the past decade is that electoral democracy has been established in Indonesia. However, fair elections are not synonymous with institutionalised democracy based on the rule of law and characterised by transparency and accountability".

Nordholt juga menyitir sebuah fakta lain bahwa, demokrasi elektoral di Indonesia bahkan, dikendalikan oleh aliansi para pimpinan partai yang menciptakan kartel politik dengan tujuan untuk mendistribusikan kekuasaan dan akses sumber daya termasuk ekonomi di antara kelompok mereka sendiri. Realita ini memang terjadi di banyak tempat di Indonesia. Sebut saja misalnya, kajian Abdur Rozaki tentang kekuasaan politik lokal di Madura. Di sana, dalam waktu yang cukup lama, keturunan kiyai yang paling dihormati di Madura, Syaikhona Kholil, berhasil mendominasi panggung politik Madura hanyakarena modal budayayang mereka miliki. Abdur Rozaki menyingkap adanya realita pemanfaatan modal budaya tersebut, yang dimiliki keturunan kiyai Syaikhona Kholil, untuk kemudian memframing pengaruh di dalam masyarakat yang ditransformasikan sebagai alat politik untuk merebut kekuasaan.

Modal budaya inilah yang pada akhirnya memudahkan mereka untuk memperoleh modal ekonomi dan modal sosial (Rozaki, 2016: 116). Apa yang terjadi di Madura, dalam setting yang hampir mirip, terjadi juga di Provinsi Nusa Tengga Timur (NTT). Meski modus operandinya berbeda, tetapi secara substansial merefleksikan hal yang hampir sama. Sejak era demokrasi langsung, hajatan politik di NTT dipenuhi aksi para aktor atau rezim politik yang secara lihai memanfaatkan jejaring relasi kuasa yang mereka miliki dengan otoritas gereja untuk mendapat manfaat elektoral. Relasi kuasa ini kemudian menjadi modal yang dikapitalisasi untuk menancapkan pengaruh ke tengah umat gereja.

Beragam cara dan mekanisme digunakan untuk terus merawat dan memperluas pengaruh. Dalam mana, di balik siasat ini, terkandung kepentingan lain yang lebih besar dari sekedar kekuasaan, yaitu untuk proteksi kepentingan ekonomi-politik. Weber dalam berbagai studinya tentang agama, sebenarnya telah mengingatkan hal tersebut. Bahwasannya, meskipun agama amat berbeda dengan politik, namun dalam hal kekuasaan, kedua-duanya memiliki kesamaan dan bahkan sering memperlihatkan kekerabatan yang erat (Weber, 2012: 478-490).

Gejala menggabungkan kekuasaan agama dan kekuasaan politik, oleh Weber disebut sebagai caesaropapisme. Gejala ini, di NTT terefleksikan dalam dua kali Pemilihan Gubernur dan beberapa pemilihan Bupati/ Wali Kota. Otoritas/hirarki gereja, (untuk tidak mengatakan seluruhnya), sering kali "tergoda" untuk berpolitik, guna memperluas pengaruh dan kekuasaannya ke ranah politik. Mereka menggunakan modal kekuasan (power) gereja, untuk mengendalikan persepsi umat. Tujuannya adalah untuk mendukung aktor atau rezim politik tertentu, yang memiliki relasi kuasa dengan mereka. Tidak hanya itu. Apa yang oleh Weber disebut sebagai gejala hierokrasi, juga terjadi di NTT.

Para aktor atau rezim politik, juga selalu mencoba masuk ke wilayah kekuasaan gereja. Melalui dramaturgi politik yang mereka mainkan, misalnya dengan memanfaatkan simbol-simbol agama dan wacana otoritas gereja, mereka mampu mendapat manfaat elektoral secara lihai dalam hampir setiap konstestasi politik. Legitimasi agama atas politik memang harus diakui tidak selalu berakibat buruk. Agama sebagai penjaga moral, bisa "menyucikan" politik. Termasuk mengarahkan secara moral semua pihak yang terlibat dalam politik agar menggunakan politik untuk tujuan kemanusiaan dan keadilan sosial. Tetapi ketika agama hanya dijadikan alat politik atau "kuda troya" semata demi meraih kekuasaan politik, maka agama telah direndahkan. Budaya politik di NTT, bahwa restu otoritas gereja adalah sebuah syarat mutlak bagi para aktor atau rezim politik untuk berkuasa, memang turut melanggengkan praktik politik ini.

Dukungan gereja sudah seperti sesuatu yang sine qua non (tidak bisa tidak ada). Siapa pun yang ingin memimpin di NTT, wajib 
mendapat dukungan gereja. Masalahnya adalah dalam hal mengupayakan restu inilah, baik pihak otoritas pemberi restu, maupun aktor atau rezim politik yang membutuhkan restu, sering kali terlibat dalam barter pengaruh. Di mana, motifnya adalah kekuasaan dan ekonomipolitik. Padahal, memanfaatkan gereja dan memanipulasi power gereja untuk kepentingan seperti itu jelas merendahkan sakralitas gereja sebagai lembaga agama yang mulia. Sebab, dalam hukum Kanonik gereja, hal itu sudah dilarang.

Gereja sebagai lembaga agama, dilarang untuk terlibat dalam politik kekuasaan atau politik praktis. Sebagaimana yang dijelaskan oleh Kristiyanto (2010: 134), bahwa, Konsili vatikan II, tahun 1963, telah menggariskan pentingnya gereja Katolik dan otoritasnya menolak 'favouritism' (favoritisme: memberi perlakuan khusus pada pihak/kelompok tertentu lebih dari yang lain) dalam politik. Gerejagereja Protestan juga memiliki dogma yang mirip.

Ajaran Jhon Calvin menegaskan bahwa dirinya percaya pada teokrasi namun bukan pada eklesiokrasi (pemerintahan negara oleh otoritas/hirarki gereja). Larangan kepada gereja untuk tidak berpolitik didasarkan juga pada fakta bahwa dalam politik praktis, tidak ada 'makan siang yang gratis. 'Politik selalu sangat pragmatis. Sebagaimana yang ditegaskan oleh filosof ilmu politik, Baggini (2003: 78) bahwa dalam politik, selalu berlaku prinsip, "Setiap mereka yang masuk ke dalam politik harus 'mengotori' sedikit tangannya, jika ingin karirnya langgeng."

Artinya, dalam hal perebutan kekuasaan politik, lembaga "yang sakral" seperti lembaga agama pun, berpeluang untuk dikotori. Dalam hal ini, gereja bisa saja hanya digunakan sebagai alat politik/'kuda troya", untuk merebut kekuasaan politik. Bukan untuk tujuan mulia "menyucikan" politik dan menjadi lembaga kritis di hadapan negara dan pemerintahan. Ketika itu terjadi maka gereja telah gagal mengemban misi mulianya sebagai lembaga agama. Kleden (2004: 43) menyebut tujuan agama adalah untuk menyelamatkan manusia (the salvation of human beings), dan memberi kemuliaan yang makin besar bagi Tuhan (the glory of God). Tetapi, realita di NTT, menunjukan hal sebaliknya.

Gereja terindikasi telah keluar dari dua tujuan itu. Selain pemanfaatan otoritas agama dalam beberapa Pilkada di NTT dan Pilgub NTT tahun 2008 dan 2013, terjadi semacam budaya politik baru, yaitu "rivalitas senyap" antara kelompok pemilih Katolik versus Protestan. Embrio fenomena ini bahkan terjadi juga dalam pemilihan Wali Kota Kupang. Tapi secara masif dan lebih kuat terekspresikan dalam dua kali Pilgub NTT. Hasil perhitungan suara dari 23 Kabupaten/Kota yang masuk ke KPUD NTT saat itu, menggambarkan betapa 'rivalitas senyap' ini nyata. Rakyat NTT terbelah. Ada polarisasi basis dukungan kepada Calon Gubernur berdasarkan identitas. Terutama identitas agama. Wacana dominan yang mengendalikan opini publik saat itu juga beraroma rivalitas identitas. Yaitu jargon Flores-KatolikversusTimor-Protestan.

Dua jargon yang saling berhadap-hadapan, tidak hanya di ruang-ruang publik fisik, tetapi juga di ruang maya firtual atau situs jejaring sosial. Jargon ini menjadi penegas bahwa, politik identitas itu nyata di NTT. Demokrasi di NTT akhirnya belum mendekati apa yang oleh Habermas disebut sebagai demokrasi deliberatif (Hardiman, 2007: 127). Sebuah model demokrasi yang berwatak diskursif. Demokrasi di NTT cenderung prosedural dan menjadi demokrasi yang tidak substantif. Bahkan dalam banyak kasus, masih sangat feodalistik dan sangat transaksional. Ini realita yang jauh dari ciri diskursivitas. Pilgub di NTT juga bahkan berubah menjadi semacam komunikasi ritual lima tahunan dalam rangka penegasan identitas pemilih.

Jika Mulyana (2005: 25) menyebut komunikasi ritual sebagai komunikasi melalui perilaku-perilaku simbolik tertentu yang bertujuan untuk menegaskan kembali komitmen emosional dan perekat bagi keterpaduan orang pada tradisi, ideologi atau agama, maka Pilgub di NTT adalah sebuah ritual penegasan identitas pemilih. Umat dibiarkan terbelah karena memiliki heteroforbia (ketakutan akan perbedaan atau rasa takut terhadap "Yang Lain"). Ketakutan (bersentuhan) ini lalu dikapitalisasi menjadi modal politik oleh para aktor atau rezim politik. Mereka dengan leluasa bisa terus mempraktikan politik "Neodevide et impera”. Yaitu sebuah taktik politik lama dengan cara kerja baru, yaitu, "Buatlah kelompok-kelompok yang berbeda agama atau etnis terisolasi satu sama lain dan takut 
bersentuhan, lalu berkuasalah" (Hardiman: 2010: 11).

Pandangan lama yang masih kuat tertanam pada pemikiran umat bahwa pihak otoritas gereja, seperti Uskup, Pastor, Imam, dan kaum selibat pada umumnya, adalah orang-orang pilihan, sumber kebenaran dan pengajar moral yang tidak bisa salah, turut mempengaruhi langgengnya budaya politik ini. Ada relasi kuasa/pengetahuan yang demikian kuat antara umat dan otoritas gereja yang menopang eksisnya budaya politik indentitas di NTT. Para aktor politik paham bahwa, umat di NTT memiliki sejenis kepatuhan kognitif dan emosional pada otoritas gereja. Kepatuhan ini bisa dimanfaatkan untuk kepentingan mobilisasi elektoral dalam kontestasi politik. Dalam pandangan umat, otoritas gereja seperti Uskup dan Pastor adalah persona-persona dengan keistimewaaan (privilese) tertentu. Cara pandang inibahkan telah menjadi apa yang oleh Bourdieu disebut sebagai habitus (Ritzer dan Goodman, 2010: 581).

Akibatnya, ketika Uskup dan Pastor sengaja menggunakan otoritas mereka, termasuk menggunakan himbauan moral sebagai strategi pendisiplinan cara pandang (power) untuk kepentingan politik, umat tidak memahaminya. Padahal himbauan moral dan religius sekali pun, sering kali adalah wujud lain dari kekuasaan. Haryatmoko (2011: 57-58), yang meminjam cara berpikir Giddens, telah menjelaskan hal itu, bahwa moral dan etika bisa menjadi alat ideologi atau kekuasaan apabila tidak ada komunikasi timbal balik atau diskursus di sana. Dalam situasi di mana terjadi komunikasi yang tidak seimbang (tanpa diskursus), pihak yang lebih inferior cenderung termanipulasi dan tereksploitasi.

Dengan bahasa lain, bisa terjadi penyesatan karena pemaknaan atau penafsiran tentang sesuatu, cenderung menyembunyikan kepentingan entah pribadi atau kelompok. Dalam hal ini, umat bisa saja terhegemoni karena Uskup dan para Pastor pada diri mereka sendiri adalah representasi kekuasaan simbolik itu sendiri. Di mana, menurut Bourdeau, atribut seperti kharisma dan keistimewaan adalah sumber kekuasaan yang krusial. Kekuasaan simbolik itu datang dari modal simbolik, seperti: harga diri, martabat, atensi (Fauzi, 2014). Dalam hal ini para Uskup dan Pastor adalah personapersona yang memiliki sumber kekuasaan jenis ini. Ketika pemilik modal simbolik (Uskup dan para Pastor) sengaja menggunakan kekuatannya (kekuasaan simbolik), di hadapan umat yang memiliki kekuatan lebih lemah, maka umat akan cenderung mengubah tingkah-lakunya, dan menormalisasi cara pandang mereka searah kuasa simbolik yang ada di hadapannya.

Dalam kerangka inilah, umat gereja telah mengalami apa yang disebut kekerasan simbolik. Atau kekerasan yang lembut (a gentle violence). Sebuah kekerasan yang tak kasat mata (imperceptible and visible). Ningtyas, (2015: 4) yang mengutip Bourdieu mengatakan, bentuk kekerasan simbolik itu 'lembut', 'kekerasan yang tidak terikat', 'kekerasan yang dibatinkan dalam sikap-sikap kepercayaan, kewajiban, loyalitas pribadi, dll. Artinya, meminjam Kleden (2004: XXIV), umat di NTT sebenarnya selama ini sedang mengalami apa yang disebut sebagai dominasi, yaitu penguasaan yang bersifat pemaksaan (coersive) karena orang secara fisik atau administratif dipaksa melalukan sesuatu yang meski dia sendiri tidak suka melakukannya. Juga hegemoni, yaitu pemaksaan secara liberal, karena yang bersangkutan seakan-akan secara sukarela melakukan sesuatu. Sebab, alam pikiran dan cara pandangnya telah diarahkan sedemikian rupa untuk mengikuti suatu wacana tertentu.

Meskipun yang terjadi di NTT memang tidak bisa disebut sebagai sebuah tabrakan peradaban, sebagaimana pemahaman Samuel Huntington dalam karyanya The Clash of Civilization. Lebih tepatnya disebut sebagai perebutan kekuasaan politik dan kapling ekonomi-politik yang meminjam agama sebagai jubah. Namun, fenomena ini menjadi sebuah budaya yang salah. Sebuah praktik politik yang secara langsung telah mendesakralisasi dan merendahkan nilai agama itu sendiri.

Agama sebagai penjaga moral umat dan patner kritis negara, telah direduksi hanya sebagai alat menggapai kekuasaan demi shawat politik mereka yang berkepentingan. Oleh karena itu, studi ini menginisiasi sebuah tanggungjawab untuk membongkar dominasi dan hegemoni, aktor atau rezim politik dan otoritas gereja di NTT yang memanfaatkan simbol-simbol keagamaan dan membangun relasi kuasa dengan motif ekonomi-politik. Sekaligus mengkritik praktik politik identitas yang telah menjadi budaya politik baru di NTT.

Tujuannya adalah untuk bisa melahirkan 
kondisi emansipatori bagi umat gereja di NTT yang selama ini terhegemoni. Dengan transformasi sosial tersebut, diharapkan akan tercipta sebuah budaya politik baru di NTT yang berwatak diskursif dan rasional. Kajian ini menggunakan pendekatan etnografi kritis, sehingga tujuan penelitian ini adalah untuk mendeskripsikan, menganalisis, dan menginterpretasikan pola-pola bertingkah laku, berkeyakinan, dan berbahasa yang diyakini bersama oleh umat, otoritas gereja, dan rezim atau aktor politik di NTT. Termasuk juga memasukan asumsi dasar critical ethnographies (etnografi kritis) yaitu menyingkap dominasi dan hegemoni yang telah berlangsung lama, dalam berbagai kontestasi politik di NTT, untuk menciptakan emansipatori di kalangan umat gereja.

Relasi kuasa dan simbol-simbol ekonomipolitik yang dimaksudkan dalam kajian ini adalah apa yang sudah menandai adanya proses komunikasi. Menurut Liliweri (2002: 5), komunikasi adalah aktivitas simbolis, yaitu mengekspresikan ide atau gagasan ke dalam objek-objek simbol dalam bentuk tulisan atau diucapkan atau simbol "bukan kata-kata verbal" (nonverbal) untuk diperagakan. Karena itu komunikasi berdimensi luas dan kompleks. Di dalamnya melibatkan proses produksi makna, distribusi makna, atau pencarian makna. Relasi kuasa dan simbol-simbol ekonomi politik selaku unit alisisis dalam kajian ini, adalah juga sebuah potret produksi makna, distribusi makna, pengiriman makna, dan bahkan manipulasi makna itu sendiri.

Karena itu, penelitian ini mencoba mengkonstruk secara sistematis makna-makna yang terkandung dalam objek yang dikaji sehingga memperoleh satu gambaran makna yang jelas dan terang. Ketika bentuk komunikasi tertentu senantiasa dipertahankan, sebagaimana yang terjadi dalam konstestasi politik di NTT, maka hal tersebut dapat dipandang sebagai sebuah praktik kebudayaan. Dalam pandangan ilmu-ilmu kritis, kebudayaan sendiri adalah sesuatu yang sangat dinamis. Kenneth Burke bahkan menyebut kebudayaan adalah kata kerja daripada sekadar kata benda (Fay, 2002: 84). Artinya, kebudayaan perlu dipahami secara semiotik. Sebagai jejaring makna (webs of significance atau fabris of meaning) atau pola-pola makna yang terwujud sebagai simbol-simbol. Karena itu, analisis terhadap kebudayaan itu sendiri harusnya juga bersifat interpretatif (Sobur, 2009: 154).

Di dalam kebudayaan sendiri, selalu beroperasi relasi kuasa/pengetahuan. Foucault menyebut hal ini sebagai operasi bio power. Di mana kekuasaan dan pengetahuan secara langsung saling menyatakan antara satu dengan yang lain. Tidak ada relasi kekuasaan tanpa dinyatakan dalam hubungannya dengan wilayah pengetahuan. Kekuasaan dan pengetahuan saling mengandaikan atau saling bertautan erat (Aur dalam Sutrisno dan Putranto, 2005: 151).

Untuk menyingkap adanya dominasi dan hegemoni dalam relasi kuasa gereja dan rezim politik, penelitian ini menggunakan metode etnografi kritis. Gagasan Madison dan Jim Thomas, juga para etnografer kritis lainnya, sebenarnya bertumpu pada asumsi bahwa sebuah kerja intelektual dalam meriset dan mendeskripsikan sebuah kebudayaan harusnya juga melangkah lebih jauh untuk mengeksplorasi beberapa fenomena tersembunyi sebagaimana dalam sebuah kebudayaan. Caranya adalah dengan berupaya membuka agenda-agenda tersembunyi di balik realitas kebudayaan tersebut guna memperbaiki keadaan pelaku kebudayaan ke arah emansipatoris (Camaroff, dan Camaroff, 1992: 87).

Critical ethnographies atau etnografi kritis juga mengharuskan para penelitinya melakukan advokasi dalam rangka emansipasi kelompok-kelompok yang termarginalkan di dalam masyarakat. Sehigga para peneliti kritis adalah mereka yang berpikiran kritis yang mencoba mencari, melalui penelitian mereka, advokasi terhadap ketidaksederajatan dan dominasi (Creswell, 2006: 56). Penelitian ini memandang objek kajiannya sebagai sebuah realita kebudayaan yang mengandung praktik dominasi dan hegemoni. Praktik ini jelas berlangsung dalam kebudayaan. Di mana kebudayaan adalah sebuah teks sosial yang perlu dimaknai karena bukan sesuatu yang berdimensi tunggal. Derrida merekomendasikan agar setiap teks sosial perlu didekonstruksi guna menyingkap pluralitas makan yang terkadung di sana. Asumsinya, adalah 1) Teks dan maknanya merupakan interpretasi imajinasi manusia dan 2) pemaknaan teks hanyalah hasil kesepakatan manusia (Al-Fayyadl, 2006: 153-164).

Selain itu, para pihak yang terlibat dalam relasi kuasa tersebut, perlu dipahami sesuai habitus, modal, dan ranah yang mereka miliki. 
Pierre Bourdieu menyebut tiga hal tersebut sebagai satu kesatuan yang menopang praktik sosial-budaya individu manusia (Bourdieu, 1990: 67-80). Termasuk bagaimana modal dan simbol yang dimiliki seseorang, bisa digunakan untuk mengoperasikan dominasi, hegemoni bahkan kekerasan simbolik. Ini dilatari oleh pemikiran bahwa, kekuasaan dan pengetahuan secara langsung saling menyatakan.

Untuk itu transfer pengetahuan melalui wacana-wacana kontra hegemoni dan advokasi, perlu dilakukan untuk mencapai keadaan emansipatori di NTT. Di mana, ruang-ruang publik perlu diisi dengan wacana-wacana pencerahan yang memantik diskusi. Ruang publik (pubic sphere) sendiri, dalam pandangan Jurgen Habermas, selalu berdimensi sosial. Di mana, mekanisme kerja ruang publik harus mengedepankan praksis komunikasi (dialog). Yaitu memaksimalkan praksis komunikasi yang sudah ada di dalam masyarakat dan berusaha meradikalkan praksis komunikasi tersebut (Hardiman, 2009: 24). Yaitu meradikalkan konsep "musyawarah - mufakat" Hardiman (2009: 48-49), menjelaskan gagasan Habermas bahwa, untuk mencapai konsensus, legitimasi ide harus dicapai melalui tindakan komunikatif. Di mana, proses konsensus sendiri memiliki 3 (tiga) ciri, yaitu: 1) Adanya kesetaraan (egaliter) tanpa memandang status atau apapun juga, 2) Menjamin adanya kebebasan dari partisipan komunikasi untuk bebas mengajukan pendapat (argument) baik dalam rangka pembelaan (afirmasi) atau kritik (negasi), 3) Tiap argumentasi yang dinyatakan harus rasional (nalar) sehingga logis dan mudah dipahami oleh partisipan yang lainnya, 4) Diskursus dilakukan dengan nuansa keterbukaan (inklusif) sehingga segala ide/gagasan yang semaksimal dan sejelas mungkin diekspresikan dalam tiap argumentasi yang dilontarkan tanpa bersikap manipulatif. Melalui diskursus, para pesertanya mencoba memecahkan berbagai persoalan sosial secara kooperatif agar konsesus yang dicapai secara intersubjektif sesuai dengan kehendak semua peserta.

\section{METODE PENELITIAN}

Penelitimenggunakan pendekatan kualitatif dengan paradigma kritis untuk membantu kerja penelitian ini. Hal ini dimaksudkan untuk memahami secara komprehensif fenomena relasi kuasa dan simbol-simbol ekonomi politik gereja dan rezim politik di NTT, serta menyingkap praktik-praktik hegemoni dan dominasi yang terselubung dalam relasi kuasa tersebut. Mulyana dan Solatun (2007: 5), mendefinisikan penelitian kualitatif sebagai penelitian yang bersifat interpretatif (menggunakan penafsiran) yang melibatkan banyak metode, dalam menelaah masalah penelitiannya. Sebagai penelitian berjenis kualitatif, penelitian ini akan dilakukan dengan cara menginterpretasikan masalah relasi kuasa dan simbol-simbol ekonomi politik gereja, berdasarkan data-data yang diperoleh dari wawancara mendalam dengan semua pihak terkait terutama umat gereja dan pihak otoritas gereja, observasi partisipasi, dan studi dokumen.

Hal ini dilakukan untuk memahami mekanisme kerja struktur-struktur yang menindas, terutama bagaimana kekuasaan politik rezim-rezim politik lokal meminjam power gereja dan otoritasnya yang memiliki modal dan simbol-simbol hegemonik untuk mengendalikan umat dalam rangka kepentingan elektoral, kekuasaan dan proteksi ekonomipolitik. Sebagai penelitian kualitatif maka penelitian ini juga akan bergerak dalam prinsip ideografis (yang mendasarkan penelitian pada pandangan bahwa seseorang hanya dapat memahami dunia sosial dengan mendapat pengetahuan langsung dari subjek yang diteliti, memperbolehkan subjektivitas seseorang berkembang dalam sifat dasar dan karakteristik selama proses penelitian) dan bukan prinsip nomotetik (yang hanya mendasarkan penelitian pada prosedur yang sistematis dengan metode ilmu alam).

Dalam bingkai prinsip ideografis tersebut peneliti membutuhkan paradigma sebagai perspektif riset atau sudut pandang kajian yang akan membingkai keseluruhan alur penelitian ini. Penelitian ini sendiri akan menggunakan paradigma kritik teori. Sebab, berkaitan dengan tujuan penelitian ini yaitu menyingkap praktik hegemoni dan dominasi terhadap umat gereja di NTT. Paradigma critical lebih bertujuan untuk memperjuangkan ide peneliti agar membawa perubahan substansial pada masyarakat. Dalam paradigma critical, peneliti wajib mencari jawaban yang melampaui penampakan di permukaan saja (fenomena) yang seringkali didominasi oleh ilusi.

Dengan melampaui yang nampak, 
penelitian ini bisa menyingkap praktik hegemoni dan dominasi untuk selanjutnya menolong masyarakat mengubah cara pandang mereka. Sehingga, keseluruhan riset ini akan bergerak dalam paradigma kritis. Paradigma kritis digunakan untuk dua hal. Yaitu untuk memahami realita (world views) relasi kuasa dan simbol-simbol ekonomi politik gereja, juga sebagai mekanisme kerja untuk mendapatkan data yang valid dan akurat serta cara yang nantinya digunakan dalam menginterpretasikan temuan di lapangan. Termasuk mengadvokasi masyarakat sejak penelitian ini dilakukan. Pemilihan paradigma ini akan memiliki implikasi pada perspektif teoretis apa yang akan digunakan secara perspektif dalam keseluruhan cara kerja metode yang dipakai.

Oleh karena menggunakan paradigma kritis, maka metode yang digunakan adalah metode etnografi kritis. Kerja metodologis ini akan ditopang oleh konsep-konsep dan teori kritis seperti konsep ideologi, hegemoni, dan dominasi dari filsuf Antonio Gramsci dan Louis Allthuserr, serta teori post-kritis dari Jurgen Habermas, Jaques Derrida, Michel Foucault dan Pierre Bourdieu. Semuanya itu akan digunakan secara taktis, sebagai sudut pandang dalam memahami, memetakan, memasuki objek penelitian, dan menganalisis temuan untuk menjadi laporan hasil penelitian. Karena penelitian ini bertujuan profetis maka kerangka berpikir peneliti dalam menggerakan perubahan umat gereja di NTT akan berada dalam paradigma kritis. Oleh karena itu, penelitian ini tidak dimaksudkan untuk menghasilkan sebuah karya ilmiah yang netral semata melainkan sebagai sebuah praksis tindakan dan gagasan kontra hegemoni dalam rangka pembebasan dan emansipasi umat gereja di NTT.

Penelitian ini menjadi gagasan alternatif yang bisa mengubah cara pandang_termasuk cara pandang otoritas gereja, juga kesadaran umat gereja pada umumnya, agar tidak lagi menerima begitu saja (taken for granted) budaya politik yang hegemonik dan dominatif tersebut. Umat, dengan memahami penelitian ini, bisa terinspirasi untuk mengkritik dan mempersoalkan cara-cara rezim atau aktor politik, juga otoritas gereja, yang memanipulasi kesadaran mereka. Umat diharapkan mampu mengawasi setiap wacana, tindakan, dan sikap gereja. Untuk itu, dalam menyajikan hasil penelitian ini, peneliti akan ditopang oleh analisis data lapangan yang diberi kekuatan argumentasi dari teori dan konsep-konsep kritis yang telah dijelaskan dalam bagian terdahulu dari penelitian ini. Dalam memahami relasi kuasa dan simbol-simbol ekonomi politik gereja di NTT, peneliti juga membutuhkan sebuah cara kerja operasional yang dapat diandalkan secara ilmiah untuk membantu peneliti dalam memperoleh pengetahuan yang objektif tentang objek dan subjek penelitian. Subjek utama penelitian ini adalah umat gereja. Pihak ini yang hendak dibantu melalui penelitian ini untuk memahami kondisi sosial mereka yang terhegemoni. Etnografi kritis sendiri merupakan sebuah metode keilmuan yang bisa digunakan untuk memahami manusia dan kebudayaanya. Karena itu, metode ini akan membantu peneliti dalam memahami realita kebudayaan, yaitu kondisi umat gereja yang terhegemoni budaya politik identitas di NTT.

Etnografi kritis dipandang relevan oleh peneliti untuk digunakan dalam riset ini karena, cara kerja etnografi kritis selalu berlandaskan pada ciri khas penelitian kritis pada umumnya, yaitu menyingkap ideologi dan berusaha membebaskan manusia yang diteliti dari hegemoni dan dominasi sebuah struktur kekuasaan, baik sosial, maupun budaya yang menindas. Sebagai sebuah kajian budaya (cultural studies), maka penelitian ini secara keseluruhan akan bergerak dalam alur kerja etnografi kritis. Pemahaman Jim Thomas dalam Kriyantono (2012: 68) bahwa metode etnografi kritis adalah metode yang bertujuan mengeksplorasi beberapa faktor seperti bagaimana kekuasaan dan hegemoni mempengaruhi masyarakat, serta berusaha membuka agenda-agenda tersembunyi dibalik fenomena tersebut.

Dalambahasalainetnografikritismerupakan etnografi konvensional dengan tujuan politik. Di mana, pengumpulan datanya dilakukan melalui 3 (tiga) teknik, yaitu: wawancara mendalam (indept interview), observasi-partisipatoris (observation-participation), dan dokumentasi visual. Sedangkan validasi data akan dilakukan melalui metode triangulasi data, yaitu melihat similaritas berbagai data yang diperoleh dari metode pengumpulan yang berbeda.

\section{HASIL DAN PEMBAHASAN}

Sebagai institusi keagamaan, gereja-gereja 
di NTT, terutama gereja Katolik, berkarya di tengah kompleksitas persoalan umat. Gereja tidak hanya berurusan dengan teologi dan ajaran iman. Posisi gereja ini dilematis dan berimplikasi pada keberadaan otoritas gereja itu sendiri. Di satu sisi, pihak otoritas (para Pastor dan Uskup) hampir setiap saat bersentuhan dengan urusan sosial kemasyarakatan. Di sisi yang lain, mereka juga masuk dalam persoalanpersoalan umat yang kadang berdimensi politis. Dalam perspektif yang positip, sebagai lembaga keagamaan sekaligus posisinya sebagai kekuatan civil society dalam negara, keterlibatan gereja dalam urusan politis (gerakan moral dan aksi damai) dalam rangka membela masyarakat yang termarginalisasi adalah sesuatu yang baik. Sebab, tugas gereja adalah memberi kritik konstruktif kepada pemerintah. Beberapa kritik terbuka dari Uskup Agung Kupang dan Uskup lainnya terhadap pemerintah Provinsi dan Kabupaten tentang kemiskinan yang akut di NTT misalnya, telah menjadi contoh bahwa gereja di NTT juga terlibat secara positip.

Masalah human trafficking yang marak di NTT juga bisa menjadi contoh bagaimana pihak otoritas gereja konsen dengan issu tersebut dan terlibataktif mengadvokasi serta membela masyarakat. Gereja dalam hal ini mendapat apresiasi sebagai penjaga moral umat, dan sekaligus kekuatan civil society yang kritis di NTT. Meskipun demikian, realita lainnya menunjukan hal berbeda. Gereja di NTT, lewat otoritasnya seperti beberapa Uskup dan Pastor, sering kali terlibat langsung dalam kegiatan politik praktis. Meskipun tentang posisi gereja dalam urusan politik, ada kelompok umat yang meyakini bahwa gereja itu memang politis. Karena sebagai sebuah institusi sosial, gereja tidak bisa diam.

Gereja butuh "menderita" dan berjuang bersama umatnya yang terdiskriminasi atau tereksklusi dalam masyarakat. Artinya, gereja diyakini tidak bisa bebas dari politik. Tetapi dalam makna yang positip sebagai kekuatan moral dalam rangka membela kemanusiaan, bukan dalam rangka kekuasaan politik. Kelompok umat lainnya di NTT meyakini bahwa harus ada pemisahan yang jelas dan tegas antara peranan gereja sebagai penjaga moral umat dan urusan kekuasaan dalam negara. Hukum Kanonik gereja telah dengan tegas menyatakan gereja tidak boleh terlibat dalam politik praktis untuk menjamin ataupun merebut kekuasaan politik. Ini kemudian sejalan dengan klaim para Uskup dan Pastor, yang selalu menyatakan secara terbuka dan tegas bahwa, gereja itu netral. Gereja tidak memihak. Karena gereja tidak boleh dan tidak pernah terlibat dalam politik praktis.

Tetapi fakta di lapangan dari studi ini justru menemukan hal sebaliknya. Dalam dua kali Pemilihan Gubernur di NTT dan dalam banyak Pemilihan Bupati dan Wali Kota Kupang, keterlibatan gereja terutama otoritas gereja Katolik dalam mendukung aktor atau rezim politik tertentu adalah nyata. Tidak bisa dipungkiri. Gereja, lewat banyak otoritasnya (untuk tidak mengatakan seluruhnya) aktif dalam politik kekuasaan. Testimoni beberapa pihak, mengafirmasi hal tersebut. Bahwa, dalam Pilgub dan Pilkada di banyak Kabupaten di NTT, otoritas gereja juga berpolitik praktis. Mengurus politik untuk kekuasaan dan manfaat ekonomi-politik. Ini ditopang oleh budaya politik warisan lama yang masih terus dihayati banyak kalangan di NTT. Kaum elit paham bahwa restu dari para pemegang otoritas gereja terutama gereja Katolik adalah penting dan krusial. Inilah yang menjadikan posisi tawar gereja menjadi demikian besar dalam politik. Sebagai agama mayoritas, pengaruh dan power gereja Katolik, adalah sesuatu yang harus diakui sangat kuat.

Dengan sistem hirarki, pengaruh ototritas di hadapan umat adalah sesuatu yang nyata. akibatnya, secara politis posisi gereja menjadi seksi dan fungsional. Bagi aktor politik, power gereja penting dan wajib digarap bahkan dikuasai dalam rangka mobilisasi elektoral dan pencitraan politik. Otoritas gereja lalu selalu diakrabi oleh siapa saja, baik pemimpin politik di level provinsi maupun kabupaten. Mereka memahami bahwa, umat gereja di NTT bisa dikendalikan, jika otoritasnya dikuasai. Umat masih memiliki konstruk kepatuhan yang tinggi kepada simbol-simbol otoritas gereja. Umat paham bahwa patuh pada otoritas adalah bagian dari iman. Semacam kewajiban moral pada "the sacred" atau yang kudus yang haram untuk dilanggar, apalagi dipertanyakan keabsahannya.

Di Flores Timur misalnya, ada sebuah istilah khusus untuk para wakil Tuhan, di mana para pastor disapa sebagai "tuan paje". Mereka ini mendapat penghormatan yang tinggi sebagai simbol yang kudusdalam masyarakat. Seorang tuan paje yang melakukan kesalahan 
sekalipun, tetap dihormati karena dipercaya sebagai kaum yang terurapi (menerima sebuah sakramen khusus dalam agama katolik). Artinya, siapa saja yang sengaja melawan tuan paje atau Pastor atau Uskup, dengan sendirinya akan dieksklusi oleh umat lainnya. Mereka dianggap berdosa oleh komunitasnya. Minimal dalam arti, melawan wakil Tuhan di dunia ini. Tindakan dan praksis hidup umat sendiri, secara berulang dan terus-menerus lalu mengokohkan rasa patuh itu menjadi budaya yang dianggap luhur dan bermoral. Kepatuhan mereka ini jika dilacak, ternyata lahir dari kuasa pengetahuan yang mereka reproduksi sendiri. Ada konstruksi pengetahuan yang dihayati bahwa adalah penting untuk menghormati simbol "the sacred" seperti Pastor dan Uskup. Jadi ada semacam bio power yang mendisiplinkan cara pandang umat bahwa mereka harus patuh pada otoritas gereja. Itu tepatnya disebut sebagai sebuah budaya.

Patuh adalah kewajiban moral dan religius. Umat lalu mengalami apa yang oleh Michel Foucault disebut sebagai relasi kuasa/ pengetahuan. Pengetahuan memproduksi sejenis kuasa mikro atau bio-power yang mendisiplinkan mereka. Sebuah kuasa yang tidak terdekteksi tetapi efeknya nyata dirasakan oleh umat dalam tindakan mereka. Temuan lainnya di lapangan menunjukan bahwa, sikap patuh pada otoritas atau kaum klerus ini lahir karena umat memandang mereka sebagai kelompok manusia khusus yang memiliki keunggulan. Baik dalam hal pengetahuan (kognisi), iman (religiositas), sikap (afeksi), maupun perilakunya. Bahkan pandangan tentang keistimewaan ini telah diinternalisasi umat gereja Katolik sedari masa kecilnya. Umat percaya bahwa para Uskup dan Pastor adalah manusia dengan privilese tertentu. Mereka adalah kaum klerus yang memegang otoritas moral.

Mereka memiliki kharisma dan kewenangan yang sah untuk menentukan sebuah kebenaran religius, bahkan juga wacana sosial. Para Uskup misalnya, harus disapa sebagai "Yang Mulia Bapak Uskup." Sebuah gelar yang merefleksikan simbol patriarki dan feodalisme lama yang khas dalam gereja Katolik. Pemimpin politik seperti Gubernur sekalipun, harus menyapa Uskup seperti itu. Mereka adalah wakil Tuhan di dunia, yang punya kuasa adi duniawi, dan menyimbolkan sesuatu yang sakral. Suara otoritas gereja (misalnya Surat Gembala Bapak Uskup) atau minimal suara para Pastor di level Paroki atau Stasi, lalu menjadi suara yang lebih dipercaya. Itu simbol suara kenabian (kebenaran). Umat percaya suara otoritas itu datang "dari atas" (Tuhan). Mereka ini kaum yang memiliki kuasa adiduniawi (suprahistoris). Artinya, hidup mereka jauh dari kepentingan duniawi. Wacana otoritas (suara Gereja) lalu lebih cepat mendapat amplifikasi dan resonansi (pembesaran dan perluasan), bahkan kepatuhan di kalangan umat di NTT. Dibandingkan dengan suara penguasa wilayah pemerintahan, seperti Bupati/Wali Kota atau Gubernur, himbauan seorang Pastor apalagi Uskup lebih didengar.

Mayoritas umat akan selalu mengalami solidaritas epistemologis, searah seruan moral gereja tanpa harus dipaksa. Umat biasnaya ternormalisasi cara pandangnya sesuai suara otoritas gereja. Karena pada level ekstrim, suara otoritas itu dipersepsi sebagai sesuatu yang tidak mungkin salah. Budaya persepsi umat terhadap suara otoritas ini yang oleh Pierre Bourdieau disebut sebagai habitus. Di mana, dalam politik, habitus ini fungsional dalam rangka mobilisasi politik dan elektoral. Artinya, para aktor atau rezim politik paham bahwa, kepatuhan umat bisa dimanfaatkan untuk kerja politik mereka. Siapa yang dekat dengan Uskup atau Pastor, akan memiliki citra yang baik di kalangan umat. sehingga, di NTT, kedekatan dengan otoritas, dan simbol-simbol gereja selalu menjadi modal politik yang sangat menentukan dalam konstestasi politik apa pun. Topangan simbol "the sacred" bagi para politisi adalah mutlak. Di NTT, Uskup dan Pastor selalu menjadi panutan.

Mereka adalah representasi kekuasaan simbolik yang nyata dan krusial secara politik. Ketika ada konstestasi politik, simbol mereka ini lalu tergoda untuk dibarter secara politik dengan aktor atau rezim politik yang membutuhkan pemilih gereja. Akibatnya, ketika suara otoritas gereja dan simbol otoritas sengaja "dibelokan/disetting" untuk kepentingan politik, umat umumnya tidak memahami itu sebagai pendisiplinan cara pandang dalam rangka mobilisasi elektoral. Hal berikutnya adalah, dalam banyak konstestasi politik termasuk Pilgub, seruan moral dari lembaga "yang sakral" ini, sengaja dimanipulasi oleh pihak tertentu sebagai alat politik. Memasuki hari $\mathrm{H}$ pemilihan Gubernur misalnya, suara 
otoritas gereja biasanya digunakan sebagai alat hegemoni dan dominasi umat (pemilih) untuk kepentingan elektoral. Penjelasan Haryatmoko bahwa, moral dan etika tidak selalu netral, tetapi bisa menjadi alat ideologi atau kekuasaan menjadi nyata di NTT.

Apalagi dengan realita bahwa, budaya diskusi dan komunikasi dialektis (diskursus) yang kritis antara umat dan otoritas gereja masih sangat sulit ditemukan di NTT, membuat umat rentan dimanipulasi. Mereka cenderungsetuju dengan arahan otoritas gereja karena kepatuhan tegak lurus. Kondisi ini membuat umat terus mengalami semacam gentleman violence atau kekerasan yang suci, dari Pemilu ke Pemilu. Mereka tidak sadar bahwa mereka terus mengalami sebuah kekerasaan yang beroperasi secara manipulatif dan halus. Karena kekerasan ini membuat orang sulit merasa bahwa ia mengalami kekerasan. Temuan lainnya yang juga menarik adalah dalam dua kali pemilihan Gubernur NTT, umat gereja tanpa diperintah, selalu secara otomatis terpolar dalam formasi berhadap-hadapan, antara pemilih Katolik versus pemilih Protestan. Situasi ini bisa disebut sebagai sebuah "rivalitas senyap" yang terus berulang atau menjadi banal karena tidak pernah dipersoalkan. Publik dan aktivis sosial di NTT tidak cukup kritis memahami hal ini sebagai sesuatu yang buruk. Budaya "rivalitas senyap" ini, secara historis, ternyata sudah berlangsung sejak lama. Sehingga bisa dikatakan sudah mengakar.

Jejaknya telah ada sejak abad pertengahan di Eropa. Lalu kemudian berlanjut ke zaman kolonial. Karena NTT adalah wilayah jajahan/ koloni bangsa Portugis yang membawa misi Katolik, dan Belanda yang membawa misi Protestan, benih rivalitas ini pun masuk ke NTT. Dalam sebuah perjanjian yang diratifikasi oleh pemerintah Portugis dan Belanda, wilayah NTT dibelah menjadi dua. Portugis menguasai pulau Flores dan sebagian wilayah di pulau Timor bagian timur, yaitu Belu, Malaka dan TTU, juga Sumba Barat Daya di pulau Sumba. Sedangkan Belanda diberi kuasauntuk menyebarkan agama Protestan di wilayah barat pulau Timor, termasuk pulau-pulau di sekitarnya yaitu Rote, Sabu, Alor, dan sebagian besar wilayah pulau Sumba. Setelah kepergian bangsa kolonial, ternyata rivalitas ini tidak langsung hilang. Benih-benih rivalitas itu masih terus hidup dan tertanam dalam budaya masyarakat.
Dalam kehidupan normal, rivalitas itu tidak terekpresikan secara ekstrim dan eksplisit. Tetapi dalam beberapa momentum, rivalitas ini sering muncul kembali. Hingga akhirnya tiba pada saat NTT resmi menjadi Provinsi otonom, lepas dari wilayah Sunda kecil. Dalam penyusunan birokrasi pemerintahan baik di level pemerintahan Provinsi NTT maupun pemerintahan Kota Kupang, rivalitas ini ternyata kembali terlihat. Penempatan pejabat berdasarkan identitas menjadi lumrah. Pengakuan banyak nara sumber menunjukan bahwa polarisasi di birokrasi berdasarkan identitas keagamaan itu sudah menjadi budaya. Puncaknya adalah, rivalitas ini menjadi sangat nyata dan terbuka saat berlangsungnya konstestasi pemilihan Gubernur di NTT. Demokrasi langsung rupanya memicu terekspresinya rivalitas lama ini secara terbuka.

Hasrat penegasan identitas masyarakat, seolah-olah di media oleh hajatan Pilgub. Ditambah dengan berbagai informasi yang ada di berbagai media. Pada prinsipnya, Media massa secara aktifmelaporkan liputan politiknya memberi dampak yang amat signifikan memberi perkembangan pendidikan politik di masa depan (Yodiansyah, 2017). Oleh karena itu, tentu saja media massa dalam masyarakat informasi, memiliki peranan yang sangat penting. Perubahan kebijakan politik, sosial, ekonomi dan pertahanan keamanan di banyak negara (Komariah \& Subekti, 2016). Dalam dua momentum Pilgub, masyarakat di hampir semua kabupaten di NTT, terbelah. Kota Kupang, yang seharusnya dalam perspektif klasifikasi sosial, masuk dalam kelompok masyarakat kelas menengah yang rasional, juga terpolar dalam rivalitas ini. Anehnya adalah, budaya ini tidak pernah dipersoalkan. Ada kesan untuk sengaja dipelihara oleh para elit dan rezim politik di NTT, karena fungsional secara politik. Bahkan ada fakta bahwa mayoritas masyarakat di NTT juga merasa nyaman dengan budaya politik ini. Mereka merasa seolah-olah semakin beragama dengan memilih calon yang seagama.

Studi ini menemukan kecenderungan pemilih untuk memilih yang seagama, karena menurut mereka dengan memilih yang seagama itu, mereka merasa telah turut serta mencecapi kembali sakralitas agama mereka. Entah sebagai seorang Katolik maupun Protestan. Kurangnya edukasi politik dari otoritas gereja kepada umat juga membuat budaya ini terus dihidupi dari 
Pemilu ke Pemilu. Ada juga fenomena lainnya bahwa, heterofobia (takut akan Yang Lain) di NTT, baru akan muncul saat adanya kontestasi politik seperti Pilgub. Dalam kehidupan setiap hari, multikulturalisme di NTT tidak bermasalah. Semuanya harmonis. NTT bisa dikatakan, benar-benar sebuah Indonesia mini.

Orang silahkan datang ke NTT untuk belajar tentang harmoni dalam kebinekaan. Tetapi itu hanya saat normal. Beda ketika dalam situasi politis. Dalam Pilgub misalnya, benih rivalitas ini akan langsung hidup. Para aktor politiklalu terus memelihara rivalitas tersebut. di mana, dalam setiap lima tahun sekali, taktik "neo devide et impera" selalu diterapkan. Masyarakat NTT dibelah dengan rivalitas agama. Peta dukungan Pilgub di NTT di tahun 2013 misalnya menunjukan dengan jelas bagaimana calon yang disebut dengan akronim Flores-Katolik, menang secara mayoritas di semua Kabupaten dengan jumlah penduduk mayoritas beragama Katolik. Sebaliknya calon Timor-Protestan menang mutlak di semua basis pemilih Protestan. Ini menjelaskan bahwa, "rivalitas senyap" memang nyata. Itu sudah menjadi budaya yang dimodifikasi sebagai komoditas politik bagi para aktor atau rezim politik.

Relasi kuasa gereja dan aktor atau rezim politik di NTT juga ternyata beroperasi dalam beragam wujud. Modusnya demikian kompleks dan tersebar dalam berbagai macam cara yang sulit terdeteksi. Biasanya hadir dalam banyak momentum dan setting peristiwa yang berbedabeda, sehingga relasi ini sulit dipahami oleh umat sebagai sesuatu yang buruk. Apalagi ketika berlangsung secara simbolik, umat sulit memahaminya. Keberagaman wujud dan cara ini menjadi masuk akal karena para pihak yang berelasi memahami bahwa umat sudah semakin melek politik.

Taktik dan strategi pun perlu terus diubah dan dioperasikan dengan rapi. Pengakuan banyak nara sumber menguatkan itu. Bahwa antara otoritas dan aktor politik biasanya sudah saling memahami. Mereka tahu, peran apa yang harus mereka lakoni agar semuanya terlihat baik dan wajar di permukaan oleh umat gereja. Setelah didekonstruksi, akhirnya tersingkap bahwa, ada motif ekonomi-politik yang bermain di balik relasi kuasa tersebut. Sebagaimana Jacques Derrida bahwa, makna teks sosial selalu plural dan tidak pernah tunggal. Studi ini menemukan makna lain bahwa, klaim otoritas gereja di NTT yanga menyatakan gereja adalah institusi keagamaan yang netral dan berdiri di atas semua golongan politik adalah tidak benar. Ada makna-makna lain dalam pernyataan tersebut yang sengaja disembunyikan (absensi). Di antaranya adalah bahwa di balik relasi kuasa yang normal dan nampak wajar, sebenarnya terdapat motif-motif ekonomi-politik yang luput dari pengamatan umat.

Pengakuan beberapa tim ahli anggota DPR RI dan DPD RI yang mewakili NTT selama beberapa periode menunjukan hal ini. Bahwa relasi berbalut kepentingan ekonomi-politik antara otoritas gereja dan aktor atau rezim politik di NTT adalah benar. Menurut pengakuan mereka, hampir semua politisi Senayan dari Dapil NTT melakukan hal tersebut. Mereka berelasi secara mesra dan kuat dengan otoritas gereja. Di balik relasi tersebut, ternyata ada barter kepentingan. Di mana, motifnya adalah ekonomi-politik. Mereka memberi contoh bagaimana keterlibatan aktor politik dalam urusan gerejani yang tentu saja punya dampak politik. Organisasi gereja-gereja Protestan di NTT, yaitu GMIT misalnya, kepengurusannya didominasi oleh para politisi. Baik yang duduk di Senayan, sebagai anggota DPR RI, maupun DPD, hingga para Bupati/Wali Kota. Karena organisasi juga membutuhkan biaya.

Dampaknya adalah, dalam setiap Pemilu, banyak Pendeta (untuk tidak mengatakan semua) terlibat langsung dalam politik. Mereka sering kali menyampaikan himbauan secara terbuka dari mimbar gereja untuk mengarahkan umat mendukung calon tertentu. Selain menjadi tokoh kunci dalam organisasi-organisasi gereja, para politisi juga bermurah hati menyumbang uang dalam jumlah besar hingga milyaran rupiah dalam mendukung kegiatan gereja. Misalnya lewat dukungan biaya untuk menyelenggarakan hajatan nikah masal untuk ribuan orang di Timor. Juga menyumbang organisasi-organisasi pemuda gereja dan wanita. Artinya, menjadi pengurus organisasi gereja dan menyumbang uang dan materi tentu bukan sesuatu yang gratis. Itu selalu bermakna simbolik. Sebab, dalam dunia politik, tidak ada "makan siang yang gratis". Bantuan biasanya berdampak secara politis. Akibatnya, relasi yang terlihat religius itu, sering kali menyembunyikan makna lain yang lebih signifikan, yaitu barter kepentingan ekonomi-politik. Fakta bahwa, banyak uang 
dan materi sumbangan bernilai milyaran rupiah yang disalurkan untuk gereja, sering kali tidak dipertanggungjawabkan secara transparan kepada umat, membuat praktik ini terus terjadi di NTT.

Kondisi dalam gereja Katolik dikemukakan oleh Pastor BUD yang saat ini sedang menjadi misionaris di Jepang. Ia menjelaskan, gereja Katolik di NTT dan di Flores, sedang mengalami pergeseran dari center (pusat)-nya. Dari kepemimpinan oleh imam-imam SVD, ke imam-imam diosesan (projo). Hal ini membawa konsekuensi yang tidak kecil. Gereja Katolik lokal lalu cenderung membangun afiliasi kurang sehat dengan penguasa-penguasa lokal, dan rezim politik lokal demi mendapat bantuan dana dan dukungan finansial. Artinya menurut pastor BUD, meskipun tidak semua tetapi kebanyakan otoritas gereja lokal, dalam usaha mengurusi hidup mereka, cenderung menempuh jalan-jalan yang tidak etis, menyalahgunakan keuangan umum (gereja), atau berkolusi dengan orangorang yang beruang atau memiliki kekuasaan. Penjelasan itu diafirmasi oleh pastor LM. Yang mengatakan bahwa, meskipun tidak seluruhnya, tetapi di banyak wilayah di NTT, Pastor dan Uskup sulit menjaga posisi dialektis dan jarak kritis gereja dengan kekuasaan negara.

Sejak Vatikan mengurangi dukungan (finansial) ke gereja lokal, kaum klerus (Pastor dan Uskup) sering kali secara diam-diam terlibat aktif dalam berbagai kontestasi politik untuk mendukung rezim politik tertentu, karena motif ekonomi-politik. Dengan demikian, realita bahwa motif ekonomi-politik selalu bermain dalam relasi kuasa gereja dan aktor atau rezim politik adalah nyata. Relasi inilah yang menjadi penentu dalam banyak proses politik di NTT. Hampir semua aktor politik paham bahwa, dengan merengkuh kekuasaan politik (power) gereja, secara otomatis umat bisa dikendalikan, dan pada akhirnya, kekuasaan ekonomi (kekayaan/wealth) juga diperoleh.

Akibatnya, hingga saat ini, relasi-relasi ini masih terus dirawat, ada yang diciptakan lagi, dipertahankan, dan dimodifikasi oleh para pihak, karena fungsional secara politik. Selain diperkuat lewat cara-cara dominatif, penguatan juga melalui cara-cara hegemonik. Yaitu melalui konstruksi pengetahuan (relasi kuasa pengetahuan lewat wacana/diskursus), agar umat menjadi tidak memahami bahwa, di balik relasi kuasa tersebut, terjadi barter kepentingan ekonomi-politik. Dalam hal ini umat gereja di NTT terus menjadi korban. Mereka hanya dijadikan komoditas politik. Sebagaimana penjelasan pastor LM, bahwa umat gereja di NTT, akhirnya hanya penting ketika ada pemilu atau menjelang gawe politik, tetapi setelah itu, mereka (umat gereja) menjadi tidak penting lagi bagi para politisi atau rezim politik.

Fenomena relasi kuasa ini akhirnya menjadi semacam indikator empirik yang menjelaskan eksistensi kebudayaan. Bahwa umat sulit mengkritik pola relasi kuasa tersebut karena mereka telah dikonstruksi oleh cara pandang budaya keagamaan yang dilegitimasi secara terus-menerus lewat praktik-praktik hidup mereka setiap hari. Menjadi Katolik miaslanya, adalah sebuah proses cultural atau yang oleh Peter L. Berger disebut sebagai konstruksi sosial atas realitas. Umat telah melalui tahap internalisasi, objektivisasi, dan eksternalisasi yang membuat mereka menjadi seorang katolik. Ketika seorang individu sudah menjadi bagian dari komunitasnya dan secara subjektif memiliki suatu diri sekaligus pandangan tentang dunianya, maka ia akan mempraktikan hal tersebut.

Ke-Katolik-an yang diinternalisasi seorang anak ke dalam dirinya, lalu menjadi identitas diri untuk kemudian menjadi sudut pandangnya dalam menilai realitas dunia. Termasuk saat ia dewasa, dan memasuki kehidupan di ruang publik. Yaitu ketika ia harus memiliki pilihan politik. Nilai yang komunitasnya legitimasikan sepanjang perjalanan hidupnya hingga dewasa, akan ia gunakan sebagai pegangan. Dalam hal ini, bisa ada banyak kemungkinan yang terjadi. Tetapi, yang paling kuat adakah ia akan mengekspresikan pilihan politiknya hanya dengan berbasiskan identitas agamanya. Padahal jika ini yang terjadi, maka ia hanya merefleksikan kembali adalah siapa dirinya sebagai orang Katolik lewat konstestasi politik seperti Pilgub atau sejenisnya. Refleksi yang hanya pada level identitas ini tentu buruk. Umat tidak paham bahwa sangat penting untuk memilih figur yang track record-nya sejalan dengan nilai-nilai ajaran agamanya atau tidak.

Track record atau rekam jejak dan visimisinya, kalah di hadapan identitas agama. Dalam hal ini, umat telah mereduksi agama hanya sebagai ekspresi identitas, dan ini artinya agama ditempatkan pada posisi yang sangat rendah. Nilai ajaran agama dan tujuan agama 
untuk memuliakan Tuhan dan mengasihi sesama manusia, tidak dijalankan. Mayoritas umat alpa memahami bahwa, identitas agama tidak menentukan nilai ajaran agama. Sebaliknya, nilai ajaran agamalah yang bisa menandai identitas agama. Hal ini terjadi karena praktik semacam itu telah menjadi apa yang oleh filosof Merleau-Ponty disebut sebagai sesuatu yang menubuh. Di mana, akibat nilai yang sudah dihayati sejak kecil dan akhirnya menubuh sebagai persepsi dan tidak disadari lagi sebagai sebuah kesalahan.

Umat bahkan memiliki sebuah pemahaman yang keliru bahwa memilih figur yang seagama adalah pembelaaan terhadap "the sacred" dalam agama mereka. Ini terjadi dalam Pilgub di NTT, di mana umat Katolik misalnya, punya semacam dorongan psikologis yang dikonstruksi secara sosial, untuk merasa seolaholah bertanggungjawab menegakan superioritas ke-Katolik-an mereka di NTT. Mereka berpikir bahwa, dengan memilih Calon Gubernur yang seagama, yaitu beragama Katolik, maka mereka sudah turut serta dalam memenangkan superioritas ke-Katolik-an. Terutama superioritas agamanya di bidang politik dan kekuasaan di NTT. Termasuk di birokrasi dan pemerintahan. Ini menandakan bahwa, Pilgub di NTT, bukan hanya sebuah pesta demokrasi, dan pemilihan pemimpin politik tetapi juga pertarungan gengsi dan supremasi group religius. Kelompok Katolik merasa penting untuk menegakan dominasinya atas kelompok Protestan, dan demikian juga sebaliknya. Ada semacam kebanggaan semu ketika kelompok mereka menang dalam konstestasi politik.

Praktik semacam ini karena terus diulang lalu menjadi banal dalam setiap kontestasi politik, sehingga mengendurkan sikap kritis umat. Mereka sulit berefleksi bahwa itu adalah sebuah sikap yang salah dan buruk. Atau sebagai malpraktik demokrasi. Ini juga didukung oleh rezim wacana yang beroperasi selama Pilgub. Di kalangan umat katolik misalnya, ada istilah "Setan Katolik". Istilah ini diciptakan oleh pihak tertentu untuk mengkonstruksi cara pandang umat. Masyarakat di banyak Paroki hingga Stasi dan Umat Basis (wilayah gereja di bawah Keuskupan) selalu menghayati jargon ini. Mereka berpikir, meskipun semua politisi itu "Setan" (orang jahat), tetapi "Setan"yang dipilih dalam Pilgub harus "Setan" dari group/ kelompok kita. Dalam hal ini adalah "Setan
Katolik". Akronim yang telah menjadi jargon wajib ini lalu menjadi wacana dominan yang biasanya menyebar lewat SMS dan obrolan warung kopi. Umat didisiplinkan bahwa meskipun yang dipilih adalah "Setan", "Setannya" harus yang seagama yaitu "Setan Katolik".

Konsturksi ini menjelaskan bahwa, pemilih dalam Pilgub di NTT pada umumnya akan selalu mengindetifikasi dirinya sesuai identitas calon. Mereka mendefinisikan diri (Self) mereka sebagai Yang Sama dengan seorang calon, sembari menolak calon lainnya sebagai Yang Lain. Yang Sama selalu bermakna mayor, sementara Yang Lain selalu bermakna minor. Itulah watak superior. Politik identitas selalu berada di rentang ketegangan antara superior dan inferior ini. Antara Yang Sama dan Yang Lain. Antara mayoritas dan minoritas. Kenyataan bahwa umat gereja sulit melakukan kritik terhadap otoritas gereja dan mereka sendiri juga sering kali tidak sadar karena kesadarannya telah dimanipulasi secara simbolik, mengisyaratkan bahwa, butuh sebuah transformasi sosial di NTT. Tujuannya adalah agar umat gereja bisa bebas dari budaya politik yang dominatif dan hegemonik. Dalam pandangan Shindunata, yang meminjam Rene Girard, sebagai institutio humana, agama termasuk gereja harus selalu diperiksa, dikupas, atau diterangkan secara ilmiah dan rasional.

Gereja merupakan suatu lembaga sosial yang mempunyai fungsi sosial dan kiranya juga mempunyai asal-usul sosial pula. Sehingga menjadikan agama hanya sebagai gejala keilahian semata yang hanya dapat dipertanggungjawabkan secara teologis belaka adalah sesat paham. Justru karena berdimensi sosial maka agama seperti gereja juga perlu dipertanggungjawabkan secara sosial. Dalam hal ini, kritik dan pengawasan dari umat gereja menjadi penting.

Menurut Teolog Katolik Ratzinger (kemudian menjadi Paus Benediktus ke XVI), kritik dan koreksi akan sangat membantu transformasi institusi "yang sakral" ini untuk kembali kepada marwahnya sebagai lembaga keagamaan. Dalam bahasa Ratzinger, agama bisa menjadi dogmatis dan ideologis jika tidak membuka diri untuk diperiksa secara nalar dan diskursif. Artinya, untuk membongkar dominasi dan hegemoniotoritas gereja dan aktor atau rezim politik di NTT, umat perlu mengaktifkan budaya diskursus dan kritik terhadap otoritas gereja. Ini 
penting dalam rangka mentransformasi budaya politik ini ke arah yang baru demi terciptanya kondisi emansipatori.

Dengan internalisasi pengetahuan baru, publik NTT dapat menjadi agen yang secara bersama-samabisa mengubah praktik-praktik kebudayaan dominatif-hegemonik tersebut. Lalumenggantikannya dengan praktik-praktik kebudayaan yang lebih emansipatif. Terutama dalam bidang politik. Umat gereja di NTT harus berani mempersoalkan semua hal yang selama ini dianggap tabu dibicarakan tentang gereja. Umat perlu memiliki sikap curiga dan kritis pada relasi gereja dan kekuasaan negara. Sebab, hanya melalui diskursus terbuka yang berwatak egaliter, argumentatif, dan inklusif, semua keburukan itu bisa disingkap dan diperbaiki. Dari situ umat gereja bisa menjadi masyarakat yang bebas dari dominasi (emansipatif) dan mampu berpolitik secara rasional dan bebas. Sebab, kondisi emansipatif sendiri selalu mengandaikan kehidupan masyarakat NTT yang merdeka, independen, humanis dan bebas dalam politik maupundalam hidup mereka secara luas.

\section{SIMPULAN}

Dari penelitian yang telah dilakukan, peneliti menyimpulkan 3 poin guna menjawabi masalah penelitian yang telah dirumuskan sebelumnya. Pertama, relasi kuasa dan simbolsimbol ekonomi politik gereja dan rezim politik di NTT telah berlangsung secara sistematis, terstruktur, dan masif. Bisa dikatakan, hal tersebut sudah menjadi satu kebudayaan politik yang dihayati oleh umat gereja dan masyarakat NTT sendiri secara luas. Studi ini sudah menujukkan secara gamblang bahwa otoritas gereja di NTT cenderung memperluas bidang kekuasaannya hingga keluar batas urusan rohani dan moral umat dan melakukan ekspansi ke dalam bidang kekuasaan negara, khususunya dalam politik kekuasaan. Hal disebut gejala hierokrasi.

Sebaliknya banyak rezim politik di NTT (untuk tidak mengatakan semua) memiliki kecenderungan yang sama untuk memperluas wilayah kekuasaannya ke bidang moral dan kerohanian umat. Gejala ini dinamakan caeseropapisme. Kemitraan gereja dan rezim politik di NTT didasari relasi simbiosis mutualisme baik yang berlangsung dalam momentum politik akbar (jelang pemilu) maupun dalam rutinitas perpolitikan. Kedua, konstestasi politik lokal di NTT lebih banyak berlangsung dalam kondisi hegemonik ketimbang dominatif. Hegemoni melibatkan ketertundukan tubuh (disiplin diri) bukan karena ancaman kekerasan fisik (dominasi), melainkan karena adanya kesadaran dari dalam diri subjek. Penelitian ini menemukan bahwa fenomena politik identitas agama di NTT merupakan satu potret kebudayaan yang telah berlangsung cukup lama. Baik gereja, rezim politik maupun masyarakat NTT sama-sama terhegemoni oleh praktik-praktik budaya politik lokal demikian.

Kondisi hegemonik bisa hadir antara gereja dengan aktor politik, aktor politik dengan masyarakat NTT, dan gereja dengan umatnya di NTT. Sederhananya, gereja, rezim politik, dan masyarakat NTT sama-sama menopang berlangsungnya praktik politik lokal di NTT. Ketiga, dengan diskursus dan deliberasi gagasan di ruang-ruang publik diharapkan bahwa, wacana contra hegemoni tentang dominasi dan hegemoni budaya politik akibat relasi kuasa gereja dan rezim/aktor politik di NTT ini bisa menemukan kekuatannya justru dari energi publik NTT itu sendiri. Lewat argumentasi-argumentasi yang lahir sebagai hasil problematisasi terhadap tema relasi kuasa tersebut, masyarakat bisa menghasilkan energi yang mampu mencerahkan mereka dan mengahasilkan sudut pandang baru tentang bagaimana seharusnya berdemokrasi. Karena hanya melalui sistem berwacana yang terbuka dan deliberatif-lah, sebuah budaya hegemonik bisa dilawan dan diperbaiki. Hanya dengan itu, mimpi mewujudkan sebuah masyarakat yang lebih egaliter dan bebas dominasi dalam momentum-momentum politik di NTT bisa digapai. Akhirnya, penelitian berpretensi bahwa praktik politik identitas agama di NTT mencederai proses demokrasi dan karenanya tidak dapat mencapai situasi dan kondisi hidup bernegara dan bermasyarakat yang ideal. Selama ini memang telah ada aktor-aktor ruang publik yang senantiasa mewacanakan buruknya kehidupan demokrasi di NTT oleh karena budaya politik identitas. Akan tetapi, wacana demikian belumlah dibakukan dalam satu kajian ilmiah yang didukung data/fakta serta interpretasi yang memadai.

Dalam kerangka kerja yang sistematis, terstruktur, lebih komplit dalam dukungan 
data, dan interpretasi yang memadai, penelitian ini diharapkan mampu menjadi sounding board yang mengstimuli diskursus publik NTT secara lebih serius terkait budaya politik identitas agama ini. Penelitian ini tidak langsung melompat pada upaya imbauan, tetapi terlebih dahulu menyajikan berbagai fakta dan interpretasi guna menggugah kesadaran masyarakat NTT tentang buruknya praktik demokrasi di NTT oleh karena budaya politik identitas selama ini. Penelitian ini menghendaki introspeksi diri baik oleh gereja, aktor politik, maupun masyarakat NTT untuk kemudian bisa melakukan transformasi perubahan budaya politik yang lebih demokratif. Upaya perubahan ini juga demi eksistensi gereja sendiri dan rezim politik, serta kebaikan hidup masyarakat NTT.

\section{DAFTAR PUSTAKA}

Al-Fayadl, M. (2005). Derrida. Yogyakarta: LKiS

Baggini, J. (2003). Making sense filsafat di balik head line berita. Jakarta Selatan: Teraju

Bourdieu, P. (1990). The field of cultural production: essays on art and literature. Cambridge: Polity $\mathrm{P}$

Camaroff, J. \& Camaroff, J. (1992). Etnography and historical imagination: studies in the ethnographic imagination. Amerika Serikat: Westview Press

Creswell, J. W. (2006). Qualitative inquiry and research design. Third Edition. London: Sage Publication

De Jonge, C. (2011). Apa itu calvinisme?, cet. Ke-7. Jakarta: BPK GM

Fay, B. (2002). Filsafat sosial kotemporer. Yogyakarta: Penerbit Jendela

Fay, B. (2002). Filsafat ilmu sosial kotemporer. Jakarta: Tadarus dan Jendela

Fauzi, F. (2014). Pierre bourdieu. menyingkap kuasa simbol. Jakarta: Penerbit Jalasutra

Foucault, M. (2000). Seks dan kekuasaan, terj. S. H. Rahayu. Jakarta: Gramedia

Hardiman, F. B. (2009). Demokrasi deliberatif. Yogyakarta: Kanisius

Hardiman, F. B. (2010). Massa, teror dan trauma. menggeledah negativitas masyarakat kita. Yogyakarta dan Maumere: Penerbit Lamalera dan Ledalero

Hardiman, F. B. (2007). Filsafat fragmentaris.
Yogyakarta: Kansius

Haryatmoko. (2011). Etika publik. untuk integritas pejabat publik dan politisi. Jakarta: Gramedia Pustaka Utama

Kleden, I. (2004). Masyarakat dan negara. Magelang: Indonesia Tera

Komariah, K. , \& Subekti, P.(2016).Penggunaan media massa sebagai agen sosialisasi dinas kesadaran masyarakat akan pentingnya imunisasi. PRofesi Humas, 1(1), 12-21

Kriyantono, R. (2012). Public relations \& crisis management. Jakarta: Kencana Prenada Media

Kristiyanto, E. O. F. M. (2008). "Sakramen politik-mempertanggungjawabkan memoria”. Yogyakarta: Penerbit Lamalera

Liliweri, A. (2002). Makna budaya dalam komunikasi antarbudaya. Yogyakarta: LkiS

Mulyana, D. (2005). Nuansa-nuansa komunikasi, meneropong politik dan budaya komunikasi masyarakat kontemporer. Bandung: Remaja Rosdakarya

Mulyana, D. \& Solatun. (2007). Metode Penelitian Komunikasi: Contoh-contoh Penelitian Kualitatif Dengan Pendekatan Praktis. Bandung: Remaja Rosdakarya

Ningtyas, E. (2015). Pierre bourdieu, language and symbolic power. Jurnal Poetika Vol. III No. 2

Nordholt, H. S. (2008). "Identity politics, citizenship and the soft state in indonesia: an essay". KITLV Leiden/VU University Amsterdam Journal of Indonesian Social Sciences and Humanities, Vol. 1, pp. 1-21.

Rozaki, A. (2016). Islam, oligarki politik, dan perlawanan sosial. Yogyakarta: SUKA Press dan Pascasarjana UIN Sunan Kalijaga Sobur, A. (2009). Semiotika komunikasi. Bandung: Remaja Rosdakarya

Sutrisno, M. dan Putranto, H (Editor). (2005). Teori-teori kebudayaan. Yokyakarta: Kanisius

Weber, M. (2012). Sosiologi agama: a handbook. Penerjemah. Yudi Santoso. Yogyakarta: IRCiSoD

Yodiansyah, H. (2017). Komunikasi politik media surat kabar dalam studi pesan realitas politik pada media cetak riau pos dan tribun. Jurnal Kajian Komunikasi, 5/1(42), 11-30. Diakses dari http://journal. unpad.ac.id/jkk/article/view/8889/5717 